\title{
沖縄地方の農業流域における土砂動態の検討 SEDIMENT MOVEMENT IN AGRICULTURAL BASIN IN OKINAWA REGION
}

\author{
大澤和敏 1 - 酒井一人 $2 \cdot$ 島田正志 $3 \cdot$ 池田駿介 4 \\ Kazutoshi OSAWA, Kazuhito SAKAI, Masashi SHIMADA, Shunsuke IKEDA \\ 1学生会員 農修 東京大学大学院 農学生命科学研究科（T113-8657 東京都文京区弥生1-1-1） \\ 2 農博 琉球大学助教授 農学部（广903-0129 沖縄県中頭郡西原町千原1） \\ 3 農博 東京大学大学院助教授 農学生命科学研究科（T113-8657 東京都文京区弥生1-1-1） \\ 4フェロー会員 工博 東京工業大学大学院教授、理工学研究科 \\ （テ152-8552 東京都目黒区大岡山2-12-1）
}

\begin{abstract}
Recently in Okinawa, red soil runoff becomes a remarkable problem, and sediment movements (erosion, transportation, and sedimentation) have to be grasped for assessments of new land development plans or sustainable managements of agriculture. A purpose of this study is to grasp the sediment movements at a watershed scale from the results of multi-point simultaneous observation in the small agricultural basin including the erosion observation. The time series of discharge, suspended sediment concentration were measured on several rainfall events and at proper intervals of time. The amount of sediment runoff from farm land and the sediment balance were calculated from observed data. It was substantiated that the low canopy covered farm lands and agricultural managements affect sediment yield, the structure and the arrangement of settling basins affect sedimentation. After the observation, USLE (Universal Soil Loss Equation) was applied and evaluated by the accuracy and the practicality as the first step to establish the prediction method of sediment runoff.
\end{abstract}

Key Words : Red soil runoff, Time series of suspended sediment runoff, Soil erosion, Multi-point field observation, Sediment balance, USLE, Settling basin

\section{1.はじめに}

沖縄県では，近年，赤土流出が顕著になり，沖縄地 方独自の自然形態を破壊する要因として問題視されて いる.このような状況の中，沖縄県は1994年に「赤土 等流出防止条例」を制定し, 各種土木事業に対して濃 度による赤土流出規制を上限 $200 \mathrm{mg} \cdot \mathrm{L}^{-1}$ と定めた。現 状では, 経常的な土砂流出発生源である農地は規制の 対象外であるが，沖縄県としては，近い将来規制対象 にする方針である。その際の規制の方法としては，グ リーンベルト, 不耕起栽培, リビングマルチなど何ら かの赤土流出防止対策を講じることを義務付けること が検討されている，営農地域を対象とした規制につい て検討するためには, 集水域内での土砂の動態(侵食, 運搬, 堆積)の現状を時間·空間的に捉え, さらに防止 対策の効果について予測する必要がある. しかし，こ れまで，農地における侵食とそれを含む集水域での土 砂流出を同時にとらえた観測事例は非常に少ない，農 業流域での土砂の動態を時間・空間的に捉えるために は，土砂生産源となる農地における侵食量観測および
複数の集水域における多点観測が必要である.さらに, 観測点での集水域が小さくなることから，これまでよ りはるかに短い時間間隔での測定が必要となる.

そこで，本研究では戋場整備事業が行われた地区を 有する小流域において多地点同時観測を行い，農地に おける侵食を含めた流域全体における土砂動態を把握 することを目的とした. 具体的には, 複数回の降雨イ ベントにおいて十分短い間隔で測定された土砂流出量 の経時変化を農地, 集水域, 沈砂池において把握する。 そして，沖縄地方における赤土流出予測手法の確立の 第一段階として, 農地における代表的な侵食モデルで あるUSLE (Universal Soil Loss Equation) を適用し，モ デルの精度や適用性を検討した。

\section{2. 観測地の概要および観測方法}

\section{（1） 観測地の概要}

対象流域は沖縄県本島恩納村の安幸地土地改良区を 含む小流域である. 図-1に流域の概要を示す．流域面 積は約 $0.125 \mathrm{~km}^{2}$ であり, 流域内には大小 51 筆の農地, 
それに付随したコンクリート製の排水路(幅:0.3 1.3m), 大小9基の沈砂池，そして下流の湿地が分布している. 2002年6月26日の土地利用を図-2に示寸．流域内にお いてサトウキビが最も多く栽培され，流域面積の $37 \%$ を占める。

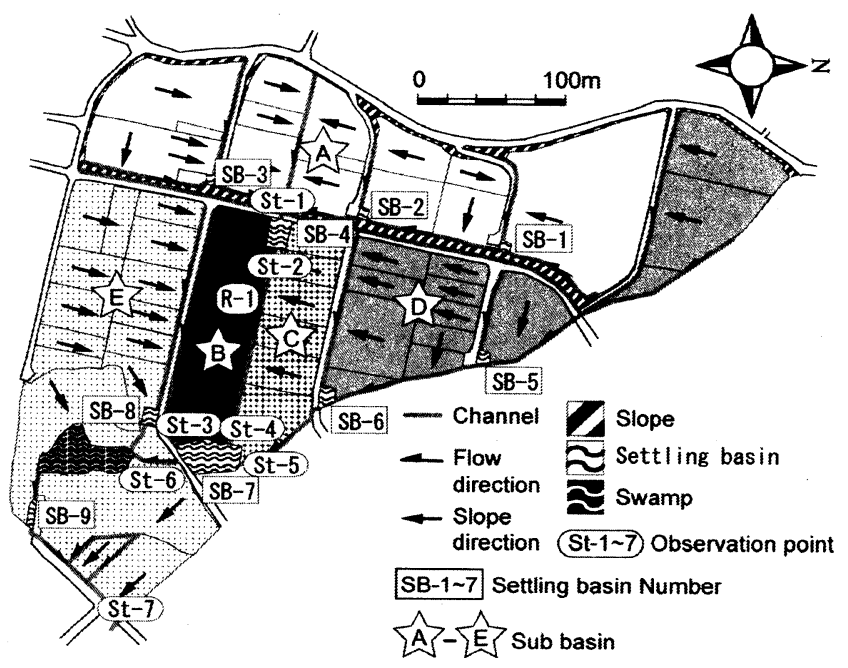

図-1 観測流域の概要

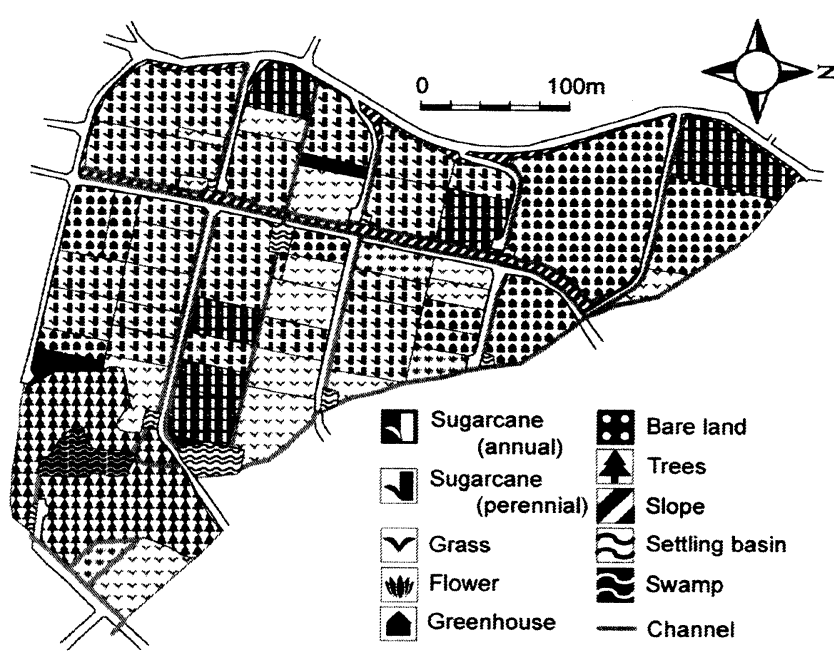

図-2＼cjkstart観測流域における土地利用分布

集水域における観測は図-1におけるSt-1 St-7の7地 点で行った. 雨量計は図中のR-1に設置した. St-1 St7の観測地点によって, 流域はA Eの集水域に分割さ れる. St-1およびSt-2は集水域A末端における沈砂池 SB-4に対応し, St-3 St-6は流域中流に位置する沈砂池 SB-7に対応する．沈砂池SB-4は約228 $\mathrm{m}^{2}$ の面積を有し, 中央部に布団籠が設置され, 流入地点 $1 つ(\mathrm{St}-1)$, 流出 地点1つ(St-2)が直線的に配置された比較的単純な構造 である. 一方, 沈砂池SB-7は約 $485 \mathrm{~m}^{2}$ の面積を有し, 流入地点 $3 つ(\mathrm{St}-3 \sim \mathrm{St}-5)$, 流出地点 $1 つ(\mathrm{St}-6)$ で沈砂池 内に布団籠および植生を有する構造である.

流域内における集水域Bを農地における侵食量観測 地点とした．図-3に概要を示す．等高線は戋場内を約 $5 \mathrm{~m} \times 5 \mathrm{~m}$ のメッシュ上の点で水準測量を行った結果で
ある. 各畑は畧が水路に垂直方向に施されており, 侵 食された土砂は畧問から水路に流出する. 各畑に执け る畧方向の平均勾配は約3\%である. 土壌は一般に国 頭マージと呼ばれる赤土であり，作土層は約 $40 \mathrm{~cm}$, 表層土の粒度組成は粘土 $9 \%$, シルト $29 \%$, 細砂およ び粗砂 $34 \%$ ，礫 $28 \%$ である，有機物含有率は7\%であ る. 降雨時に外部からの表面流の流入は無い. サトウ キビ畑，S-1に対応する観測点，St-3aで長期連続観測 を行い，作物の生育期間である約 1 年間を通して観測 を継続した。それに加えて，サトウキビ畑，S-2 S-3 に対応するSt-3b St-3cで多点同時観測を行い，短期間 ではあるが同じ降雨イベントで複数の戋場における侵 食量を比較できるようにした，各圃場の特徴を表-1に 示す. 各围場においてサトウキビの栽培方法や生育状 態などが異なる．サトウキビは3 4月に植え付けを行 い，翌年の2 3月に刘り取りを行う春植え型と刈り取 り後の株を用いて生育させる株出し型の 2 種類の方法 で栽培されている。

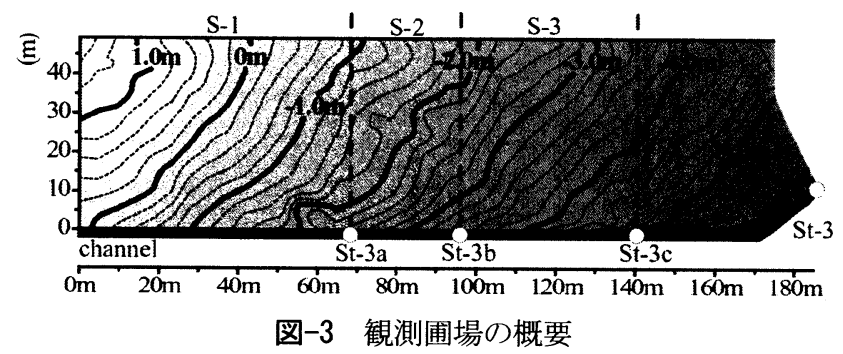

表-1 各観測戋場の特徵

\begin{tabular}{|c|c|c|c|c|}
\hline 場庍 & fE型 & 面積 $\left(\mathbf{m}^{2}\right)$ & 観測項目，期聞 & 被被 $(\%)$ \\
\hline $\begin{array}{l}\text { St-3a } \\
(\mathrm{S}-1) \\
\end{array}$ & 株出し & 3343 & $\begin{array}{c}\text { 流量, 浮遊砂濃度 } \\
2002.5 / 11 \sim 2003.4 / 30\end{array}$ & $79.9^{*}$ \\
\hline $\begin{array}{l}\text { St-3b } \\
(\mathrm{S}-2)\end{array}$ & 春植え & 1010 & $\begin{array}{c}\text { 浮遊砂濃度 } \\
2002.6 / 10 \sim 6 / 16\end{array}$ & $34.3 *$ \\
\hline \multirow{2}{*}{$\begin{array}{l}\text { St-3c } \\
(\mathrm{S}-3)\end{array}$} & 株出し & 1053 & 浮遊砂濃度 & $64.9 *$ \\
\hline & 春植え & 1204 & $2002.6 / 10 \sim 6 / 16$ & $50.7 *$ \\
\hline
\end{tabular}

\section{（2）観測方法}

各観測地点における観測項目を表-2に示す，流量は 水位を常時連続計測することによって換算される. St-7以外の堰は, JISに規定されている条件を満たさな いので流量観測により H-Q曲線を作成した(決定係数 : 0.97以上)。また，St-3bおよびSt-3cは流量の測定がで きなかったので, 上流側のSt-3a と下流側のSt-3の観測 值と圈場面積を用いて内挿した。 浮遊土砂濃度は降雨 流出時の流水を採取して吸引濾過法または直接炉乾す ることによって測定される．なお，浮遊土砂を流水中 に存在する土粒子(浮遊砂とウォッシュロードの混合, 最大粒径 $100 \mu \mathrm{m}$ 程度) と定義する. 取水は手採水また は自動採水器によって行われた。手採水による採水時 間間隔は流出規模に応じて, 流量増加時では短く, 
表-2 各観測地点における観測項目

\begin{tabular}{|c|c|c|c|}
\hline 地点 & 項目 & 時間間隔 & 測定機器 \\
\hline \multirow{4}{*}{ St-1 $\sim$ St-6 } & 流量 & - & 全幅堰(自作，検定なし) \\
\hline & 水位 & 1分 & $\begin{array}{l}\text { 圧力式水位計 } \\
\text { (Diver, (株)大起理化工業) }\end{array}$ \\
\hline & 流速 & 適時* & $\begin{array}{l}\text { プロペラ式流速計 } \\
\text { (SAT-200-10,(株)東京計測) }\end{array}$ \\
\hline & 採水 & 5〜60分* & 手採水 \\
\hline \multirow{5}{*}{ St-7 } & 流量 & - & 全幅堰 (自作, JIS基準) \\
\hline & 水位 & 5分 & $\begin{array}{l}\text { 圧力式水位計 } \\
\text { (KADEC21-MIZU, } \\
\text { (株)コーナシステム) }\end{array}$ \\
\hline & 流速 & 適時* & $\begin{array}{l}\text { プロペラ式流速計 } \\
\text { (SAT-200-10, (株)東京計測) }\end{array}$ \\
\hline & 濁度 & 5分 & $\begin{array}{l}\text { 後方錯乱光式濁度計 } \\
\text { (UC-61H, (株)セントラル科学) }\end{array}$ \\
\hline & 採水 & 30分* & 自動採水器 (ISCO 6700, ISCO社) \\
\hline \multirow{4}{*}{ St-3a } & 流量 & - & 四角堰 (自作，検定済み) \\
\hline & 水位 & 1 分 & $\begin{array}{l}\text { 圧力式水位計 } \\
\text { (UIZ-WL500,(株)ウイジン) }\end{array}$ \\
\hline & 濁度 & 2 5分 & $\begin{array}{l}\text { 後方錯乱光式濁度計 } \\
\text { (COMPACT-CLW, } \\
\text { (株)アレック電子) }\end{array}$ \\
\hline & 採水 & 10分* & 自動採水器 (ISCO 6700, ISCO社) \\
\hline St-3b, St-3c & 採水 & 5 10分* & 手採水 \\
\hline $\mathrm{R}-1$ & 降水量 & 1分 & $\begin{array}{l}\text { 転倒マス式雨量計 } \\
\text { (RG 2-M, } \\
\text { オンセットコンピュータ社) }\end{array}$ \\
\hline
\end{tabular}

ピーク後の流量が減少するにつれて間隔を徐々に長く とった．St-3aおよびSt-7では採水の間の濃度を内挿す るために濁度計を用いて常時連続計測した．観測によ り得られた流量と浮遊土砂濃度の積から浮遊土砂流出 量が求められる. なお, St-3aにおいて, 比較的規模の 大きい降雨イベント時に堰部に土砂の堆砂があったの で，その量はイベント毎に浚渫し計量した。 その結果, 堆砂量は, 降雨イベントによって若干異なるが，浮遊
食量を浮遊土砂流出量と堆砂量の和と定義する．観測 期間はSt-3a の長期連続観測を除き(表-1参照)， 2002 年6月10日〜16日までの期間で，沖縄地方では梅雨時 期であった.

\section{3. 観測結果}

\section{（1）農地における侵食量観測の結果}

多点同時観測期間における流量，浮遊土砂濃度，浮 遊土砂流出量，そして降水量を図-4に示寸．観測期間 内における降雨イベントは2002年6月10日，6月12 13 日，6月13日，そして6月15 16日の4回あり，イベント 毎に線で区切って表示した. 流量は対応する農地の単 位面積当りの流出高で示し, 浮遊土砂流出量も対応す る農地の単位面積当りの流出量で示した．浮遊土砂濃 度は各観測点における值なので，上流地点の影響を受 けた結果となっている，そこで，浮遊土砂流出量で比 較すると，多くのピーク部分においてSt-3a $<$ St-3c < St-3bの関係になっていることがわかる。これは，栽 培方法の違いにより，植生の被覆率，地表面における 残渣被覆, そして耕起回数が圈場によって異なること が影響していると考えられる。

長期連続観測点のSt-3aにおける流量および侵食量を 図-5に示寸。なお，それぞれの值は，降雨イベント単 位で示した. データが得られたのは55回のイベント中, 43 回で総降雨量 $1687 \mathrm{~mm}$ 中の $1475 \mathrm{~mm}$ であった。図に 示した降雨イベントは，後述するUSLEで定められた 侵食性の降雨時のみである．降雨-流出の傾向を見る と, 時期的な変化は明確に見られなかったことから, サトウキビの生長に伴う表面流出の変化は小さいこと がわかる，一方，侵食量はサトウキビの生長に伴い，

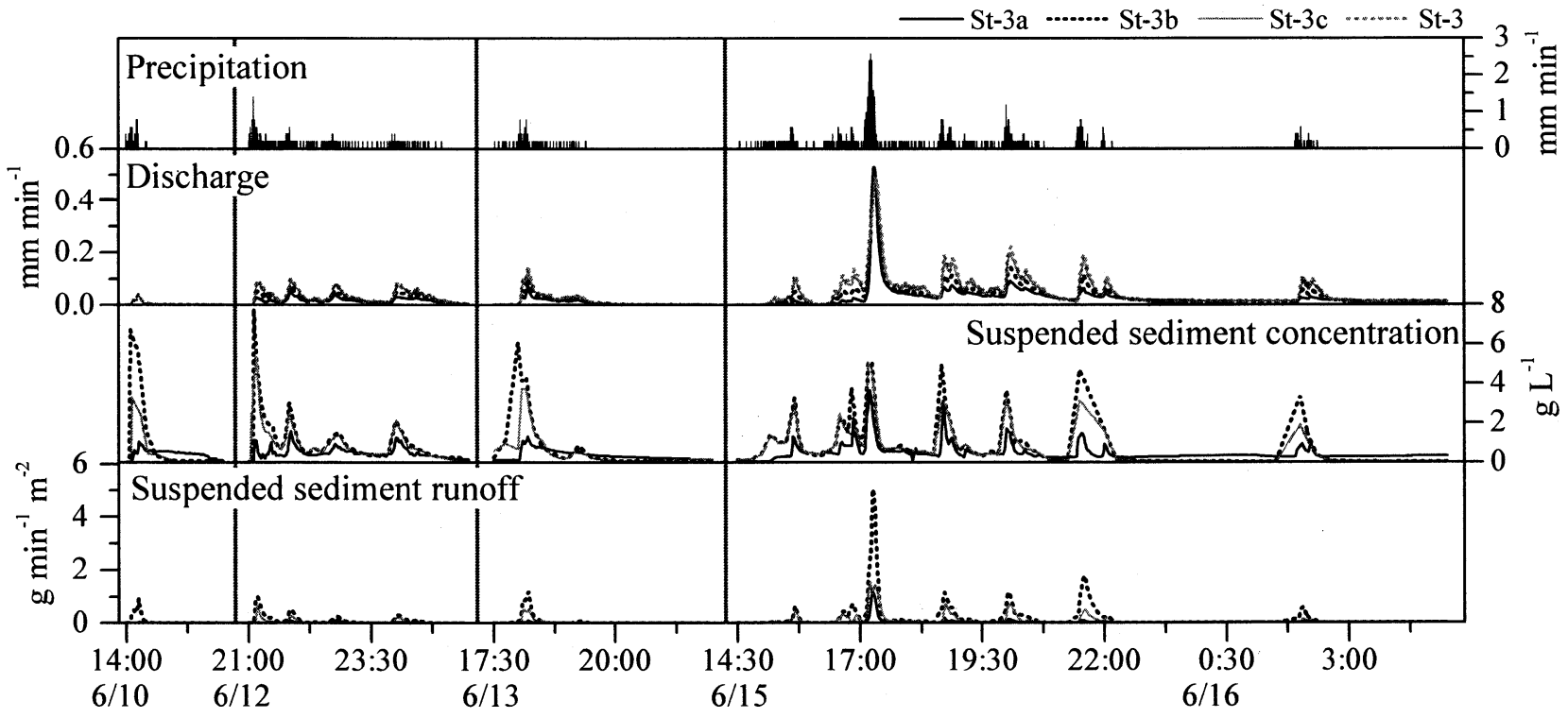

図-4 St-3a, St-3b, St-3cそしてSt-3(流量のみ)における篗測結果 (上:降水量, 中上:流量, 中下:浮遊土砂濃度, 下:浮遊土砂流出量) 土砂流出量の約 $15 \%$ であった. 以後, 農地における侵 低下していることがわかる. よって, 雨滴の遮断によ 


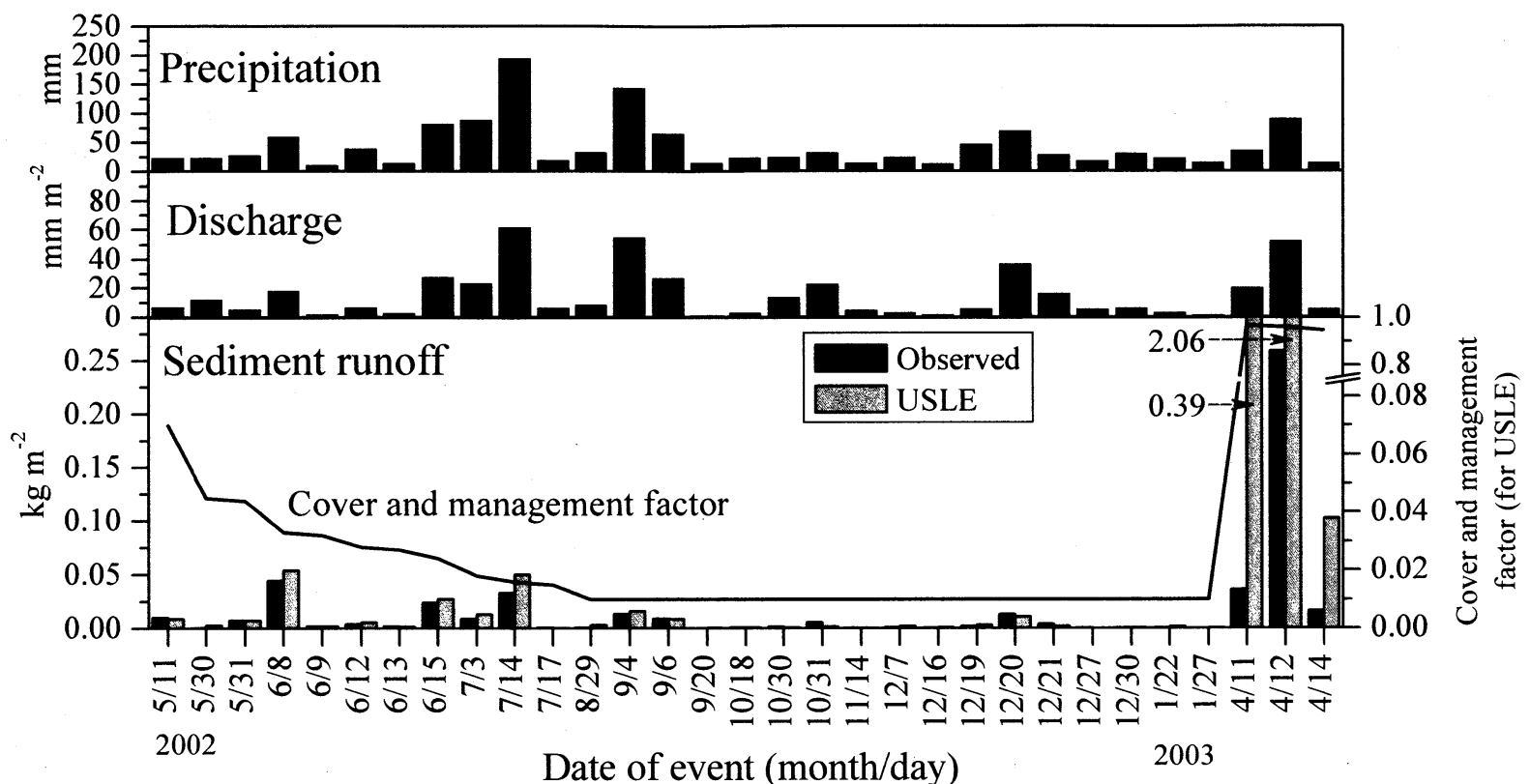

図-5 St-3aにおける観測値とUSLEによる計算值 (上: 降水量, 中: 流量, 下: 侵食量)

り雨滴侵食が抑えられていることが言える。また，収 穫および耕起後の 2003 年4月の降雨イベントでは，非 常に大きい侵食量を示した.

\section{（2）流域における土砂収支}

St-1 St-7の集水域における観測地点で得られた浮遊 土砂流出量から，各降雨イベントにおける土砂収支を 図-6にまとめた。なお，各地点における数值の正値は 浮遊土砂の堆砂量を示し，負值は観測点における浮遊 土砂流出量を示す。沈砂池では堆砂，集水域内では侵 食に伴う土砂生産が起きたことがわかる。なお，今後， 集水域における土砂生産量を各観測点における浮遊土 砂流出量の絶対值(正值)として表現する．集水域Aで は観測されたイベントは2回あるが，いずれの結果で も土砂生産量が大きい。これは，サトウキビや裸地な どの受食性の高い土地利用の面積が大きいことによる. また，集水域内には3基の沈砂池を有するが，沈砂池 を介さない農地が複数あることも原因である。このこ とは，集水域Bにおいても同様であり，集水面積は小 さいが，集水域全体が受食性の高い土地利用のために 土砂生産量が大きい，逆に，集水域 $\mathrm{B}$ と同等な集水面 積を持つ集水域Cは，受食性の高い土地利用面積が小 さいので土砂生産量は小さい傾向にある。集水域Dは 集水域Cより受食性の高い土地利用面積が大きいのに も関わらず，土砂生産量は同等または小さい。これは 集水域D内には小規模の沈砂池が2基あり，それらの 配置が全ての農地に対応していることによって，土砂 の流出が軽減されていると予想される.

ここで, 沈砂池SB-4 と沈砂池SB-7の堆砂量を検討す る. 堆砂率は沈砂池SB-4において6/12:29\%，6/13： デー夕無し，6/15:9\%, 沈砂池SB-7では6/12:45\%, 6/13:41\%, 6/15:29\%となり, 沈砂池SB-7の方が沈
砂池SB-4より堆砂量および堆砂率が大きい。これは, 沈砂池における規模(貯水容量), 流入部と流出部の位 置関係，そして布団籠や植生などの抵抗の有無に起因 するものと考えられる. イベント毎の堆砂率を比較す ると, 両沈砂池において大きなイベント(6/15)の場合, 堆砂率は比較的小さなイベント $(6 / 12 や 6 / 13)$ より低い ことがわかる. 特に, 小規模の沈砂池の方が堆砂率の 低下が著しい。

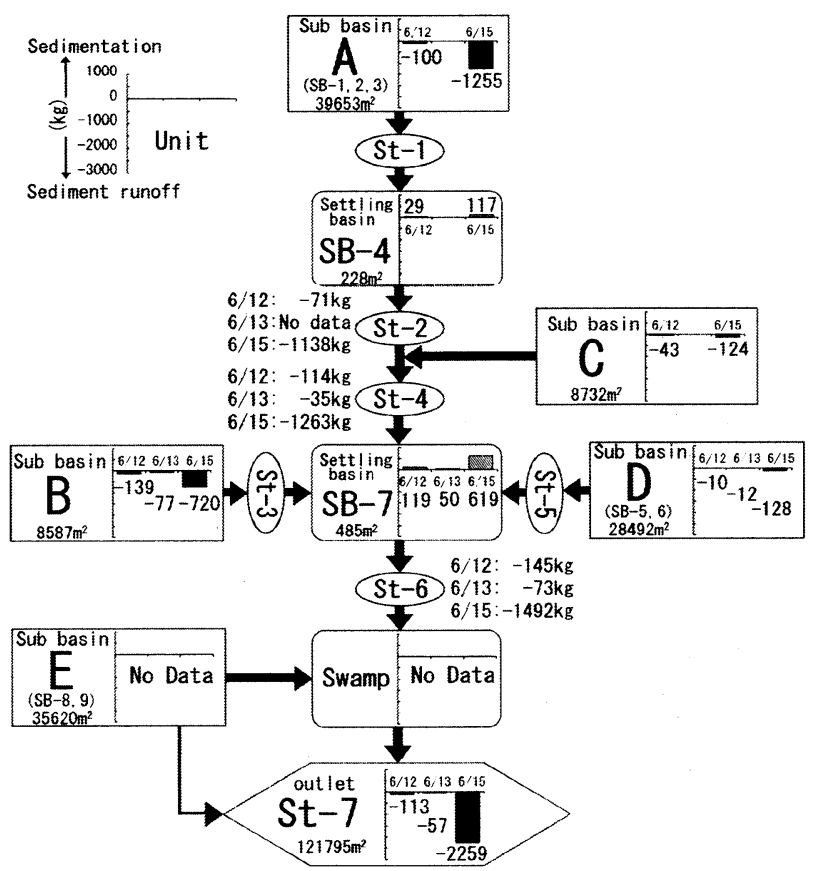

図-6＼cjkstart流域全体における土砂収支

\section{4. 農地におけるUSLEの適用}

USLEはWischmeier・Smithらによってまとめられた 経験的モデルであり，嘎場単位の空間スケールにおけ 
る年間流亡土砂量が推定可能とされている1). USLEは 適用事例が多く, 沖縄地方への適用例もあるが, 降雨 イベント単位での検証は行われていない. 一方, 西村 ${ }^{2)}$ はUSLEの問題点について述べている. 本研究では, 沖縄地方における赤土流出予測手法の確立の第一段階 として, USLEの適用を降雨イベント毎に行い, 農地 における侵食量観測結果および各集水域の浮遊土砂流 出量観測結果に対する計算值の比較を行う.

\section{（1）USLEの適用方法}

USLEは次式のように定式化されている.

$$
A=R \cdot K \cdot L S \cdot C \cdot P
$$

ここで $A$ :予測侵食量 $\left(\mathrm{kg} \cdot \mathrm{m}^{-2}\right), R:$ 降雨係数 $\left(\mathrm{J} \cdot \mathrm{m} \cdot \mathrm{h}^{-1} \cdot \mathrm{m}^{-2}\right)$, $K$ : 土袞係数 $\left(\mathrm{kg} \cdot \mathrm{h} \cdot \mathrm{J}^{-1} \cdot \mathrm{m}^{-1}\right), L S$ :地形倸数(以下無次元), $C$ :作物管理係数, $P$ :保全係数. USLEでは, 一連降雨 を降水量が $12.7 \mathrm{~mm}$ 以上または降雨強度が $6.4 \mathrm{~mm} / 15 \mathrm{~min}$ 以上の降雨で, 降雨後の無降雨期間が6時間以上と定 義している. 一連降雨での降雨係数Rは次式となる.

$$
\begin{gathered}
R=E \cdot I_{30} \times 10^{-3} \\
E=\sum\left\{\left(11.9+8.73 \log I_{i}\right) \cdot r_{i}\right\}
\end{gathered}
$$

ここで， $E$ :侵食性一連降雨の運動エネルギー $\left(\mathrm{J} \cdot \mathrm{m}^{-2}\right)$, $I_{30}$ : 一連降雨の最大 30 分間降雨強度 $\left(\mathrm{mm} \cdot \mathrm{h}^{-1}\right), I_{i}$ : 一定強 度に区分された各降雨強度 $\left(\mathrm{mm} \cdot \mathrm{h}^{-1}\right), r_{i}$ :一定強度に区 分された降水量 $(\mathrm{mm})$. 土壤係数Kは土䁃特有の受食性 (水の浸透能や土粒子の分散性)を年間平均值として評 価したものであり，定数として用いられる. 降雨イベ ント毎の適用のためには, その值を経時的に変化させ る必要があるが, 本研究では, 比嘉・満本 ${ }^{3)} ゙$ 用いた 国頭マージの0.031を期間全体で用いた。この值は翁 長ら ${ }^{4)}$ が観測侵食量を用いて逆算した値(0.019 0.057) の範囲内にある. 地形係数 $L S$ は勾配を畧方向にとって 算出した. 作物管理係数Cは作物の種類や围場管理作 業を評価したものであり, サトウキビの作物管理係数 は, 比嘉ら ${ }^{5)} ゙$ 作成した作物の成育段階別の值および 実測した圃場の被覆率を用いて降雨イベント毎に算出 した(図-5実線)，その他の土地利用における作物管理 係数はWischmeierら ${ }^{1)}$ の值を参照した。保全係数Pは保 全対策が行われていないので1とした.

\section{（2）農地における侵食量観測に対する適用結果}

多点同時観測時のSt-3a 3cにおける適用結果を図-7 に示す．結果を見ると，若干の過大評価する箇所があ るが，概ね適合性が高いことがわかる．これより，本 研究で用いた各係数は適切であったことが確認できる 特に, 降雨イベント毎で算出した降雨係数や作物管理 係数を用いても精度上, 問題無いことがわかった.

St-3aにおける長期連続観測期間に対する適用結果を 前章の図-5に示した. 結果を見ると, サトウキビの収 穫前(2003年3月)までの精度が高い。特に, 作物管理

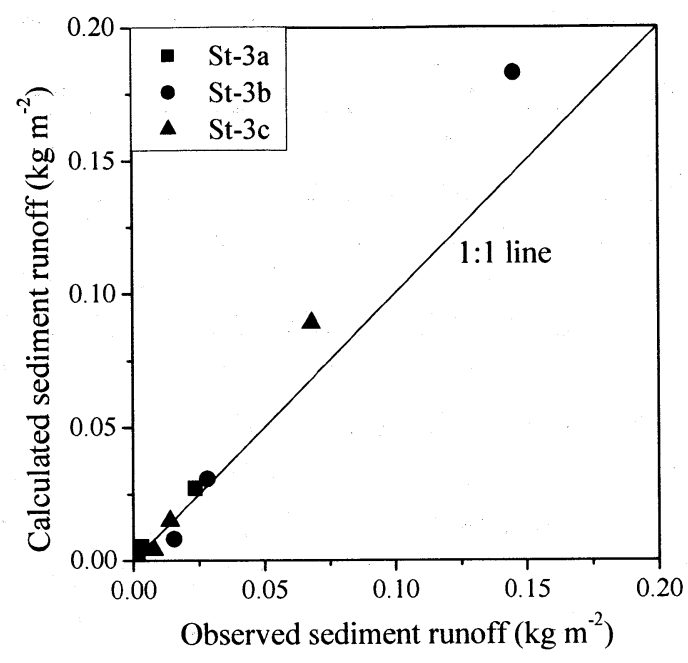

図-7 USLEの適用結果 (多点同時観測)

係数を時変的に更新させたことで，5月から6月におけ るサトウキビの生長期において観測値と適合性が高い. 一方, 植え付け後の 4 月の降雨イベントでは著しく過 大評価する.これは, イベントの直前に耕起を行った ために, 透水性をはじめとする土壤の諸状態が大きく 変化したことや土中および地表面に残渣が大量に存在 したのにも関わらず，土㙥係数を一定值 $(0.031)$ とし， 作物管理係数をほぼ1としたためであると考えられる. このようにUSLEは耕起などの管理作業に伴う土壌状 態の変動を反映させることが困難であると言える.

\section{（3）流域内の農地における侵食量の算定結果}

前節の結果より, 耕起直後を除いた期間ではUSLE の適用結果は概ね良好であったので, 流域全体の農地 にUSLEを適用した。適用した降雨イベントは6/12, 6/13, そして6/15で，6/15における適用結果を図-8に 示寸. 結果から, サトウキビや被覆率の比較的小さい 草地などの受食性の高い土地利用の農地において大き な值を示していることがわかる。ここで, USLEの計 算値を $\mathrm{A}$ Eの集水域毎に集計し, 観測結果と比較した ものを表-3に示す. なお, 観測值は集水域の末端にお ける浮遊土砂流出量なので, 集水域内の沈砂池などに

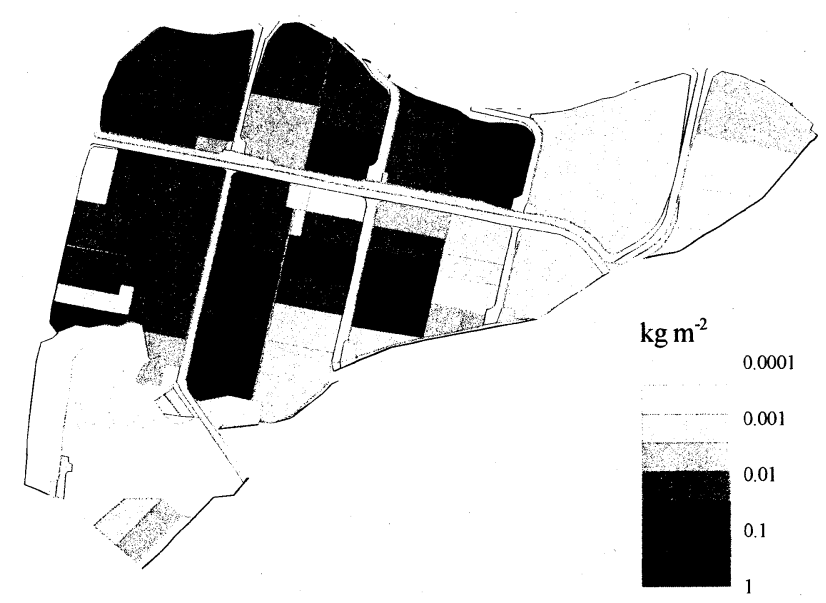

図-8ＵSLEによって算定された侵食量分布 (6/15のイベント) 
表-3 各集水域におけるUSLEによる計算値および観測値

\begin{tabular}{cccc}
\hline 集水域 / 日 & $6 / 12$ & $6 / 13$ & $6 / 15$ \\
\hline A & $221 / 100$ & $58 /$ No data & $1313 / 1255$ \\
\hline$B$ & $160 / 139$ & $42 / 77$ & $951 / 720$ \\
\hline C & $21 / 43$ & $5 /$ No data & $122 / 124$ \\
\hline D & $33 / 10$ & $9 / 12$ & $195 / 128$ \\
\hline E & $82 /$ No data & 21/No data & $484 /$ No data \\
\hline \hline
\end{tabular}

USLEによる計算值 $(\mathrm{kg}) /$ 集水域末端における観測値 $(\mathrm{kg})$

おける堆砂量が差し引かれた值である．結果を見ると， 各集水域において概ね妥当な侵食量を算定していると 評価できる．集水域Bでは，沈砂池は無いが，全体が 受食性の高い土地利用の農地なので誤差が大きい傾向 にある。一方，集水域Aおよび集水域Dでも過大評価 する傾向にある。これは，計算値は集水域内にある沈 砂池の堆砂量を考慮していない影響と考えられる．集 水域Cでは妥当な計算值と評価できる.

ここで，表-3における観測值の得られなかった集水 域Eの計算值と図-6のSt-7およで沈砂池SR-7の浮遊土 砂流出量を見ると，集水域Eおよび沈砂池SB-7の下流 に湿地があるのにも関わらず，6/15では湿地において 流入土砂量以上の浮遊土砂流出量がSt-7で観測されて いる。これは，湿地もしくはSt-7の水路における土砂 の再懸濁や湿地周辺の法面の崩壊などが考えられるが, 現段階では明確な判断ができない．他の降雨イベント (612, 6/13)では湿地における堆砂が認められる.

\section{6. おわりに}

農業流域における多地点同時観測において，流域全 体における土砂の動態を把握した．また，流域内にお ける主要な土砂流出源であるサトウキビ畑において， 侵食量の長期連続観測および多点同時観測を行った. 観測において, 流量, 浮遊土砂濃度の測定間隔を十分 小さくとることによって，浮遊土砂流出量の経時変化 を把握することができた，そして，代表的な土壌侵食 モデルであるUSLEを適用し，モデルの検証を行った.

観測結果から次のことが明らかになった。

・ サトウキビの株出し栽培圃場(St-3a)において, 営 農周期(約1年)を通して長期連続観測を行った結果, 侵食量は作物の生長に伴い減少する傾向を示した. また，耕起などの管理作業によって侵食量は増大 した．サトウキビの異なる栽培方法(春植え栽培) が行われている戋場も含めて多点同時観測を行っ た結果，株出し栽培戋場の方が春植え栽培圃場よ り侵食量が小さい結果を得た。

- 流域全体における土砂収支をとることによって, 各流域における土砂生産は土地利用，流下途中の 沈砂池の構造およびその配置，そしてイベント規 模によって浮遊土砂流出量の大小関係が異なる傾
向にあることがわかった。サトウキビや裸地など の受食性の高い土地利用が土砂生産の支配要因と なっている。

・沈砂池の規模が大きくなるほど，形状が複雑にな るほど，そして，植生や布団籠などの抵抗を有す る場合，堆砂率は増大寸る傾向にある．降雨イ心゙ ント規模が大きくなると堆砂率は低下する。 その 低下率は，沈砂池の規模が小さくなると増大する.

USLEは本来，年間流亡土砂量の算定に用いられる が，本研究では降雨イベント単位での適用を試みた。 農地における観測地に適用した結果，耕起直後の降雨 イベントを除いた大部分のイベントにおいて，観測さ れた侵食量と高い適合性が確認できた。しかし， USLEは耕起による土㙵の攪乱を計算值に反映するこ とが困難であることがわかった，そして，流域内の全 ての農地における適用の結果，集水域毎の観測値と概 ね適合した。しかし，USLEは沈砂池などにおける堆 砂および再懸濁の評価ができないこ上や耕起なら゙の営 農作業を明確に表現できないことが欠点であり，流域 規模における適用や営農作業による土砂流出軽減対策 を講じることは難しい，よって，今後，そのような問 題が改善できるWEPP (Water Erosion Prediction Project) 6)の適用や新たなモデルの開発を行う予定である.

謝辞 : 本研究の現地観測にあたり，様々な御支援を頂 いた東京大学大学院農学生命科学研究科水利環境工学 研究室の諸氏, 琉球大学農学部利水工学研究室の諸氏, 東京工業大学大学院理工学研究科池田研究室および総 合理工学研究科石川研究室の諸氏，そして観測地の農 家の諸氏に心からお礼を申し上げます，なお，この研 究は文部科学省科学研究費基盤研究(A)(2)(課題番号 : 14205070, 研究代表者: 池田駿介)の支援によって行 われた。

\section{参考文献}

1) Wischmeier, W.H. and D.D. Smith: Predicting rainfall-erosion losses, Agricultural Handbook No.537, USDA Washington D.C., 1978.

2) 西村 拓: 精密土壌・環境保全のための数値予測方法, 農業土木学 会誌, Vol.66, No.9, pp.933-939, 1998

3) 比嘉 榮三郎, 満本 裕彰: USLE式による土壌流出予測方法, 沖縄 県衛生環境研究所報, Vol.35, pp.121-128, 2001.

4) 翁長 謙良, 吳屋 昭, 松村 輝久: 沖縄県北部赤黄色土の土䁃侵食 の評価と対策, 土壌の物理性, Vol.63, pp.19-33, 1991.

5) 比嘉 榮三郎, 大見謝 辰夫, 仲宗根 一哉, 満本 裕彰: 沖縄県にお ける各種作物の作物係数, 沖縄県衛生環境研究所報, Vol.31, pp.147-151, 1997.

6) Ascough II, J.C., C. Baffaut, M.A. Nearing, B. Y. Liu: The WEPP Watershed Model: I. Hydrology and Erosion, Transactions of the ASAE, Vol.40, No.4, pp.921-933, 1997.

（2003.10.1受付） 